\title{
PROMJENE U OBILJEŽJIMA TURISTIČKE POTROŠNJE RIJEČKIH I OPATIJSKIH TURISTA
}

Svrha je rada utvrditi postoje li promjene $u$ visini, strukturi i determinantama turističke potrošnje ostvarene u destinaciji u 2016. godini u odnosu na 2014. godinu, odnosno utvrditi u kojim je segmentima turističke potrošnje došlo do promjene u dvogodišnjem razdoblju. Kvantitativna analiza temelji se na uzorku od 1.198 anketnih upitnika koje su popunili turisti koji su boravili na području Rijeke i riječkog prstena i Opatijske rivijere tijekom ljeta 2014. i 2016. godine. T-test za nezavisne uzorke upotrijebljen je da bi se utvrdile statistički značajne razlike između obilježja ispitanika koji su u destinacijama boravili 2014. i onih koji su tamo boravili 2016. godine. Dvije regresijske analize provedene su zasebno na ispitanicima iz 2014. godine $i$ zasebno na ispitanicima iz 2016. godine radi utvrdivanja čimbenika koji utječu na visinu prosječne dnevne potrošnje. Rezultati su ukazali na to kako postoje značajne razlike i $u$ visini i u strukturi turističke potrošnje ostvarene u 2016. godini u odnosu na onu koju su turisti ostvarili 2014. godine. Uz navedeno, rezultati su ukazali na to kako se razlikuju i čimbenici koji utječu na visinu potrošnje ostvarene u dvije obrađene godine.

Ključne riječi: turistička potrošnja, determinante potrošnje, struktura potrošnje, turizam

* Dr. sc. D. Soldić Frleta, docentica, Fakultet za menadžment u turizmu i ugostiteljstvu Sveučilišta u Rijeci (E-mail: danielas@fthm.hr).

${ }^{* *}$ Dr. sc. D. Smolčić Jurdana, redovita profesorica, Fakultet za menadžment u turizmu i ugostiteljstvu Sveučilišta u Rijeci (E-mail: doras@fthm.hr).

Rad je primljen u uredništvo 11.12.2017. godine, a prihvaćen je za objavu 05.07.2018. godine.

Ovaj rad nastao je u sklopu projekta ZP UNIRI 3/15 Sveučilišta u Rijeci. 


\section{Uvod}

S obzirom na kontinuirane promjene na turističkom tržištu, veliku konkurenciju, ulaganja u razvoj destinacija kao i na promjene obrazaca ponašanja turista, neophodno je kontinuirano istraživati razinu i strukturu potrošnje turista na razini destinacije. Uz navedeno, još je važnije pratiti odrednice turističke potrošnje koje se također mijenjaju, a sve u cilju mogućeg povećanja ekonomskih utjecaja turizma na destinaciju. Kada se utvrde čimbenici koji utječu na turističku potrošnju u destinaciji, moguće je djelotvorno i učinkovito primjenjivati utvrđene determinante u procesu segmentacije tržišta kao i pri kreiranju turističkih proizvoda i usluga po mjeri potrošača koje destinacija želi privući. Stoga znanje o visini i strukturi turističke potrošnje ostvarene u destinaciji kao i poznavanje čimbenika koji utječu na nju predstavljaju kvalitetne smjernice pri odlučivanju o budućim pravcima razvoja destinacije. Analiza literature ukazuje na manji broj radova koji se bave istraživanjem turističke potrošnje na razini destinacije u odnosu na makrorazinu. Razlog tome leži u činjenici da su agregatni podatci lakše dostupni na makrorazini, dok su podatci o ponašanju turista - potrošača - kao i o čimbenicima koji utječu na njihovu potrošnju teže dostupni (Brida \& Scuderi, 2013, Craggs \& Schofield, 2009, Fredman, 2008, Mak, 2004). U tom je kontekstu u slučaju Hrvatske potrebno istaknuti tržišno istraživanje koje provodi Institut za turizam pod nazivom TOMAS Ljeto. Radi se o istraživanju koje je povezano s turističkom potražnjom i turističkom potrošnjom te koje se već duži niz godina kontinuirano provodi u intervalima od tri do četiri godine u primorskim županijama RH. Važno je naglasiti da se podatci navedenog istraživanja koje, među ostalim, rezultira vrijednim informacijama o prosječnoj dnevnoj potrošnji u destinaciji prema županiji, zemlji porijekla, organizaciji putovanja i vrsti smještajnog objekta, ne primjenjuju i za utvrđivanje čimbenika koji su u značajnoj mjeri povezani s ostvarenom visinom potrošnje turista. Stoga je svrha ovog rada, uslijed očigledne potrebe za istraživanjima u čijem je fokusu utvrđivanje determinanti turističke potrošnje na razini destinacije, upravo utvrditi odrednice turističke potrošnje i to na dvjema skupinama ispitanika: onih koji su na području Opatijske rivijere i Rijeke i riječkog prstena boravili 2014. i onih koji su u tim destinacijama boravili 2016. godine. Nadalje, cilj je bio utvrditi i postoje li, osim u determinantama, i promjene u visini te strukturi turističke potrošnje ostvarene u destinaciji u 2016. godine u odnosu na 2014. godinu

U skladu s istraživanjem TOMAS Ljeto iz 2014. godine (Institut za turizam, 2015), unatoč povećanju prosječne turističke potrošnje na razini primorskih županija, važno je napomenuti da je potrošnja turista na području Primorsko-goranske županije bila ispod prosječne potrošnje turista u Hrvatskoj. Rezultati istraživanja TOMAS Ljeto pokazali su da su u 2014. godini turisti u hrvatskim priobalnim županijama u prosjeku trošili $66 €$, dok su na području Primorsko-goranske županije 
trošili tek nešto više od $57 €$ (Institut za turizam, 2015). No potrebno je naglasiti da je na području Opatijske rivijere i Rijeke i riječkog prstena situacija u pogledu visine prosječne dnevne potrošnje nešto drugačija zbog specifične strukture njihovih smještajnih kapaciteta u kojima veliki udio otpada na hotelski smještaj. Ove dvije susjedne destinacije svojim se specifičnostima međusobno nadopunjuju i sve su prepoznatljivije na turističkom tržištu. Naime, na području Opatijske rivijere i Rijeke i riječkog prstena 2016. godine ostvareno je više od dva milijuna noćenja, što predstavlja $15 \%$ ukupnih noćenja Primorsko-goranske županije i $3 \%$ ukupnih noćenja u Hrvatskoj (Državni zavod za statistiku, 2017). Uz navedeno, obje destinacije suočavaju se s iznimnom sezonalnošću. Naime, u skladu s podatcima Državnog zavoda za statistiku (2015, 2017), od svibnja do kraja kolovoza 2014. godine Opatijsku rivijeru i Rijeku i riječki prsten posjetilo je više od 429 tisuća turista (što čini više od $55 \%$ ukupno ostvarenih dolazaka), dok ih je 2016. godine posjetilo više od 793 tisuće turista, od čega je njih više od $55 \%$ u destinacijama boravilo tijekom ljetnih mjeseci. Ipak, potrebno je naglasiti da se podatcima o turističkom prometu koji ne odražavaju obrasce turističke potrošnje ne može mjeriti ekonomski utjecaj turizma na destinaciju (Wang \& Davidson, 2010) jer ishodište svakog ekonomskog utjecaja turizma leži upravo u turističkoj potrošnji (Mihalič, 2002; Frechtling, 2006). Stoga je u tom kontekstu za sve dionike u ovim destinacijama, a posebice za destinacijske menadžere i kreatore politike, važno utvrditi koji čimbenici utječu na odluke o turističkoj potrošnji (Marrocu et al., 2015) kao i utvrditi promjene koje se događaju kada je riječ o turističkoj potrošnji koja se realizira na razini destinacije. Na taj se način može ostvariti podloga za povećanje ekonomskih učinaka turizma, odnosno za dugoročnu ekonomsku održivost destinacija.

\section{Teorijski okvir}

Analiza prethodnih istraživanja povezana s turističkom potrošnjom ukazuje na to da je veći broj onih autora koji su se bavili istraživanjem i analizom turističke potrošnje na makrorazini, čiji je cilj utvrđivanje doprinosa turizma cjelokupnom gospodarstvu (Brida \& Scuderi, 2013; Craggs i Schofield, 2009; Fredman, 2008). No Frechtling (2006) naglašava kako je istodobno važno i razumijevanje turističke potrošnje pri mjerenju ekonomskih utjecaja turizma na destinaciju. Stoga je sve veći broj onih autora koji se bave utvrđivanjem determinanti turističke potrošnje na razini destinacije, a važnost istraživanja potrošnje turista u postizanju boljeg razumijevanja gospodarskog utjecaja turizma na destinaciju dokazana je brojnim studijama (primjerice Craggs \& Schofield, 2009, Disegna \& Osti, 2016., Fredman, 2008, Hung et al., 2012; Legohérel i Wong, 2006; Thrane, 2014). U skladu sa sveobuhvatnim pregledom radova koji su se bavili istraživanjem turističke potrošnje 
na razini destinacije, a koji su prezentirali Brida \& Scuderi (2013), najviše autora primjenjuje klasičan linearan regresijski model u kojemu je turistička potrošnja modelirana metodom najmanjih kvadrata (OLS), dok je manji broj onih koji primjenjuju naprednije ekonometrijske modele kao što su double-hurdle, Tobit ili Heckit modeli (Mayer \& Vogt, 2016). Kad je riječ o turističkoj potrošnji kao zavisnoj varijabli, u literaturi se razine potrošnje izražavaju četirima kategorijama: ukupnom potrošnjom tijekom cijelog putovanja (po grupi, po kućanstvu, po ispitaniku), dnevnom potrošnjom, potrošnjom po osobi i dnevnom potrošnjom po osobi (Brida \& Scuderi, 2013). Brojni autori potvrđuju da različite varijable mogu utjecati na razinu turističke potrošnje u destinaciji (Brida \& Scuderi, 2013, Disegna \& Osti, 2016, Marcussen, 2011, Thrane, 2016.). Navedene se varijable najčešće grupiraju, također u četiri glavne kategorije: ekonomske, sociodemografske, varijable povezane s putovanjem i boravkom te psihografske varijable (Marcussen, 2011; Marrocu et al., 2015; Thrane, 2016). U grupi ekonomskih varijabli autori najčešće testiraju vezu između turističke potrošnje i primanja ispitanika te u većini slučajeva potvrđuju pozitivnu statističku značajnu vezu (primjerice Downward \& Lumsdon, 2003; Cannon i Ford, 2002; Fredman, 2008; García-Sánchez et al., 2013; Marrocu et al., 2015; Thrane, 2014, 2016). Sociodemografske varijable uključuju dob, spol, bračno stanje, razinu obrazovanja, zanimanje, mjesto stanovanja, nacionalnost, veličinu i sastav kućanstva i slično. U slučaju sociodemografskih varijabli, empirijski nalazi njihova utjecaja na turističku potrošnju vrlo su često potpuno različiti. Dob i spol najčešće su primjenjivane sociodemografske varijable, ali je znakovito da postoje brojni primjeri i negativnih i pozitivnih učinaka dobi i spola na turističku potrošnju (Brida \& Scuderi, 2013; Thrane, 2016). Slični nalazi također se bilježe kada je riječ i o učincima porijekla, stupnja obrazovanja, zanimanja, boravišta i nacionalnosti na turističku potrošnju (Brida \& Scuderi, 2013). Primjerice, prema Mayeru \& Vogtu (2016), neki autori u svojim istraživanjima potvrđuju statistički značajnu vezu među razinom obrazovanja, zanimanjem i turističkom potrošnjom, dok drugi ne dolaze do takvih rezultata, što bi se najvjerojatnije moglo objasniti multikolineralnosti s varijablom primanja.

Varijable povezane s putovanjem i boravkom u destinaciji najčešće uključuju prijevozno sredstvo, tip smještajnog kapaciteta, svrhu putovanja, dužinu boravka, veličinu i sastav grupe koja putuje zajedno, tip organizacije putovanja i boravka, aktivnosti u destinaciji, prethodna putovanja i slično. I u ovom slučaju različiti autori bilježe neujednačene učinke navedenih varijabli na visinu turističke potrošnje (Wang \& Davidson, 2010). Ipak, brojni su autori potvrdili da prijevozno sredstvo (primjerice Downward \& Lumsdon, 2004; Fredman, 2008; García-Sánchez et al., 2013; Thrane, 2014, 2016) i tip smještajnog kapaciteta (primjerice García-Sánchez et al., 2013; Laesser i Crouch, 2006; Svensson et al., 2011; Thrane, 2014, 2016.) statistički značajno utječu na visinu potrošnje turista. Među varijablama povezanima s boravkom turista u destinaciji, autori najčešće testiraju vezu između duljine bo- 
ravka i visine turističke potrošnje, pri čemu ih većina potvrđuje statistički značajnu vezu između ove dvije varijable (Brida \& Scuderi, 2013). Ovdje je potrebno napomenuti da je ta veza obično pozitivna ako se analizira turistička potrošnja tijekom cijelog boravka, dok je utjecaj duljine boravka negativan ako je zavisna varijabla dnevna turistička potrošnja (Mayer \& Vogt, 2016). Nadalje, veličina i sastav grupe koja putuje zajedno također su bile među najčešće primjenjivanim nezavisnim varijablama i u mnogim su se slučajevima pokazale kao važni prediktori turističke potrošnje (Brida \& Scuderi, 2013), ali se i u ovom slučaju rezultati razlikuju od studije do studije jer neki autori potvrđuju pozitivnu, a drugi negativnu značajnu vezu između tih varijabli i turističke potrošnje (Wang \& Davidson, 2010). Slično je i s učincima organizacije putovanja i boravka kao i aktivnostima kojima se turisti bave u destinaciji, pri čemu se u literaturi mogu naći slučajevi pozitivnih, ali i negativnih veza ovih varijabli s turističkom potrošnjom (Brida \& Scuderi, 2013). Nadalje, i kada je riječ o broju posjeta destinaciji, autori su došli do različitih rezultata - naime više studija pokazalo je da broj dolazaka nije u značajnoj mjeri povezan s potrošnjom (Brida \& Scuderi, 2013), dok su neki autori (primjerice Craggs \& Schofield, 2009; Downward \& Lumsdon, 2003) ipak utvrdili statistički značajnu povezanost broja posjeta i turističke potrošnje.

Posljednja skupina varijabli koje autori dovode u vezu s turističkom potrošnjom odnosi se na psihografske varijable. Ova skupina varijabli uključuje motivaciju, stavove turista, psihološke karakteristike i slično (Wang \& Davidson, 2010). Analiza dosadašnjih istraživanja ukazala je na to da autori rijetko uključuju ove varijable u svoje modele (Brida \& Scuderi, 2013; Wang et al., 2006), što implicira potrebu za daljnjim istraživanjem njihova utjecaja na turističku potrošnju. Svakako je primjetan povećan interes autora za testiranjem ovih varijabli jer u zadnjih nekoliko godina raste broj objavljenih istraživanja koja uključuju psihografske varijable, kao što je stupanj zadovoljstva turista (npr. Chen \& Chang 2012; Craggs \& Schofield, 2009; Disegna \& Osti, 2016, Kim et al., 2010; Wang \& Davidson, 2010; Zhang et al., 2010).

U skladu s prethodno navedenim, vidljivo je da su mnogi autori objavili različite rezultate kada je riječ o utjecajima pojedinih varijabli na razinu turističke potrošnje. Naime, kod nekih su se autora određene varijable pokazale kao značajan prediktor turističke potrošnje, dok kod drugih to isto nije potvrđeno. Štoviše, u nekim istraživanjima rezultati pokazuju da određene varijable pozitivno utječu na potrošnja, iako je u drugim studijama pronađen negativan odnos. Stoga je očito da postoji potreba za daljnjim istraživanjem ove problematike (Wang \& Davidson, 2010). Naglašavajući važnost turističke potrošnje, Mak (2004) zaključuje da je područje ponašanja turista kao potrošača još uvijek nedovoljno istraženo te da ga je zbog njegove specifičnosti potrebno dalje istraživati. 


\section{Metodologija istraživanja}

Podatci upotrijebljeni u ovom radu dobiveni su anketiranjem turista koji su boravili na području Rijeke i riječkog prstena te Opatijske rivijere. Anketirani su turisti u dobi od 18 ili više godina koji su u navedenim destinacijama od svibnja do kraja kolovoza 2014., odnosno 2016. godine proveli najmanje jednu noć. Anketari su slučajnim odabirom pristupali turistima, a svi su upitnici prikupljeni odmah nakon završetka popunjavanja u prisustvu anketara.

Osnovni instrument prikupljanja primarnih podataka bili su anketni upitnici tiskani na hrvatskome, engleskome, njemačkome i talijanskome jeziku koje su turisti samostalno popunjavali uz prisutnost člana istraživačkog tima koji im je uvijek bio na raspolaganju. Anketni upitnik sastoji se od 47 varijabli grupiranih u četiri cjeline. U prvom se dijelu upitnika s pomoću 22 tvrdnje mjeri stupanj zadovoljstva različitim elementima ponude turističke destinacije. Nakon ocjene pojedinačnih elemenata, jednom tvrdnjom utvrđuje se stupanj ukupnog zadovoljstva ponudom. Ispitanici su tvrdnje ocjenjivali na Likertovoj ljestvici s pet ocjena, $s$ krajnjim mjerama 1 - u potpunosti nezadovoljan i 5 - u potpunosti zadovoljan. U drugom dijelu upitnika ispituje se sociodemografski profil turista, dok je cilj trećeg dijela bio dobiti podatke o obilježjima putovanja i njihova boravka u destinaciji. Posljednji dio upitnika prikupljao je podatke o ukupnoj potrošnji turista kao i njezinoj strukturi. Ispitanici su zasebno iznosili visinu svoje potrošnje za sedam kategorija (smještaj; hrana i piće; zabava i kultura; sport i rekreacija; kupovina; izleti i ostali troškovi u destinaciji). 2014. godine je prikupljeno ukupno 523 upitnika, što je rezultiralo stopom odaziva od $74 \%$, dok je 2016. godine prikupljeno 675 anketnih upitnika (stopa odaziva $76 \%$ ). Prikupljeni podatci iz navedenih 1.198 anketnih upitnika analizirani su statističkim paketom SPSS za Windows 24.0. Analiza podataka obuhvatila je deskriptivnu statistiku, t-test za nezavisne uzorke i regresijsku analizu. Deskriptivna statistika upotrijebljena je za profiliranje uzorka, a t-test za nezavisne uzorke upotrijebljen je za utvrđivanje statistički značajnih razlika u obilježjima i potrošnji turista koji su boravili u navedenim destinacijama ljeti 2014. u odnosu na one koji su tamo boravili ljeti 2016. godine. Naposljetku su provedene dvije regresijske analize, zasebno za 2014. godinu i 2016. godinu, kojima je cilj bio utvrditi koji čimbenici utječu na visinu turističke potrošnje i razlikuju li se oni s obzirom na vrijeme boravka ispitanika u odabranim destinacijama. 


\section{Rezultati i analiza istraživanja}

U skladu s vremenskom dinamikom kretanja turističkog prometa koji se ostvaruje u odabranim destinacijama, u obje promatrane godine najviše je ispitanika anketirano u kolovozu (33,9 \%), zatim u srpnju (26,4 \%), dok je najmanje ispitanika anketirano u lipnju (20,5\%) i svibnju (19,2\%) (Tablica 1).

Tablica 1 .

VREMENSKA I PROSTORNA DISTRIBUCIJA ANKETNIH UPITNIKA $(\mathrm{N}=$ 1198)

\begin{tabular}{|c|c|c|c|c|}
\hline & $\begin{array}{c}\text { Ukupno } \\
\mathrm{N}=1198 \\
\%\end{array}$ & $\begin{array}{c}2014 \\
\mathrm{~N}=523 \\
\%\end{array}$ & $\begin{array}{c}2016 \\
\mathrm{~N}=675 \\
\%\end{array}$ & dvosmjerni t-test \\
\hline Mjesec & & & & \multirow{5}{*}{$\begin{array}{l}t=-0,575 \\
p=0,566\end{array}$} \\
\hline Svibanj & 19,2 & 19,5 & 19,0 & \\
\hline Lipanj & 20,5 & 21,2 & 20,0 & \\
\hline Srpanj & 26,4 & 26,2 & 26,5 & \\
\hline Kolovoz & 33,9 & 33,1 & 34,5 & \\
\hline Destinacija & & & & \multirow{3}{*}{$\begin{array}{l}t=1,687 \\
p=0,092\end{array}$} \\
\hline Opatijska rivijera & 66,1 & 63,5 & 68,1 & \\
\hline Rijeka i riječki prsten & 33,9 & 36,5 & 31,9 & \\
\hline
\end{tabular}

U skladu s prostornom dinamikom ostvarenih dolazaka i noćenja na promatranom području u obje godine, anketirano je više ispitanika koji su boravili na području Opatijske rivijere nego onih s područja Rijeke i riječkog prstena. U skladu s podatcima iz Tablice 1, 66,1\% ispitanika boravilo je na Opatijskoj rivijeri, dok je njih 33,9 \% boravilo na području Rijeke i riječkog prstena.

\subsection{Profil ispitanika}

Analiza sociodemografskog profila pokazuje da je uzorak prilično ujednačen kada je riječ o spolu ispitanika (47,2 \% muških i 52,8 \% ženskih ispitanika). Najveći udio ispitanika (45,1\%) ima između 36 i 55 godina starosti (Tablica 2). 


\section{Tablica 2.}

\section{SOCIODEMOGRAFSKI PROFIL ISPITANIKA}

\begin{tabular}{|c|c|c|c|c|}
\hline Obilježje & $\begin{array}{c}\text { Ukupno } \\
\mathrm{N}=1198 \\
\%\end{array}$ & $\begin{array}{c}2014 . \\
\mathrm{N}=523 \\
\%\end{array}$ & $\begin{array}{c}2016 . \\
N=675 \\
\%\end{array}$ & dvosmjerni t-test \\
\hline \multicolumn{5}{|l|}{ Spol } \\
\hline Muški & 47,2 & 48,9 & 45,9 & \multirow{2}{*}{$\begin{array}{l}t=-1,039 \\
p=0,299\end{array}$} \\
\hline Ženski & 52,8 & 51,1 & 54,1 & \\
\hline \multicolumn{5}{|l|}{ Dob } \\
\hline$<=25$ & 8,3 & 6,9 & 9,3 & \multirow{6}{*}{$\begin{array}{l}t=-0,276 \\
p=0,782\end{array}$} \\
\hline $26-35$ & 29,1 & 32,1 & 26,8 & \\
\hline $36-45$ & 22,7 & 22,6 & 22,8 & \\
\hline $46-55$ & 22,5 & 21,2 & 23,6 & \\
\hline $56-65$ & 12,3 & 11,5 & 12,9 & \\
\hline $66+$ & 5,1 & 5,7 & 4,6 & \\
\hline \multicolumn{5}{|l|}{ Razina obrazovanja } \\
\hline Osnovna škola & 1,0 & 1,1 & 0,9 & \multirow{5}{*}{$\begin{array}{l}t=7,380^{*} \\
p=0,000\end{array}$} \\
\hline Srednja škola & 34,7 & 27,0 & 40,7 & \\
\hline Viša škola & 29,1 & 23,5 & 33,5 & \\
\hline Fakultet $i$ više & 34,9 & 48,2 & 24,6 & \\
\hline Ostalo & 0,3 & 0,2 & 0,3 & \\
\hline \multicolumn{5}{|c|}{ Mjesečna primanja kućanstva } \\
\hline do $1.000 €$ & 14,5 & 13,5 & 15,2 & \multirow{4}{*}{$\begin{array}{l}t=1,940 \\
p=0,053\end{array}$} \\
\hline $1.001-2.000 €$ & 37,4 & 33,5 & 40,6 & \\
\hline $2.001-3.000 €$ & 28,8 & 34,1 & 24,6 & \\
\hline $3.001 € i$ više & 19,3 & 18,9 & 19,6 & \\
\hline \multicolumn{5}{|l|}{ Zemlja porijekla } \\
\hline Domaći & 16,0 & 14,1 & 17,5 & \multirow{2}{*}{$\begin{aligned} t & =1,577 \\
p & =0,115\end{aligned}$} \\
\hline Strani & 84,0 & 85,9 & 82,5 & \\
\hline
\end{tabular}

Napomena: * signifikantno uz teorijsku razinu signifikantnosti od $1 \%$

Nadalje, 37,4 \% ispitanika ima prosječna mjesečna primanja u rasponu od 1.000 do 2.000 eura, a tek $19,3 \%$ njih ima prosječna mjesečna primanja kućanstva viša od 3.000 eura. Očekivano, značajno je više stranih $(84,0 \%)$ u odnosu na domaće ispitanike (16,0 \%). T- testom utvrđeno je da, uz teorijsku razinu signifikantnosti od $5 \%$, ne postoji statistički značajna razlika između ispitanika iz 2014. godine i onih iz 2016. godine kada su u pitanju spol, dob, mjesečna primanja i zemlja porijekla ispitanika (Tablica 2). 
S druge strane, t-testom utvrđena je statistički značajna razlika u obrazovnoj strukturi dviju navedenih grupa ispitanika. Naime, 48,2 \% ispitanika koji su na području Opatijske rivijere i Rijeke i riječkog prstena boravili 2014. godine bili su fakultetski obrazovani, dok je takvih gostiju 2016. godine boravilo samo $24,6 \%$. U 2016. godini najviše je bilo ispitanika sa završenim srednjoškolskim obrazovanjem $(40,7 \%)$.

U skladu s podatcima prikazanima u Tablici 3, ispitanici su u većini slučajeva putovanje organizirali individualno, s tim da je potvrđena statistički značajna razlika između ispitanika koji su boravili u ovim destinacijama 2014. godine u odnosu na one koji su tamo boravili 2016. godine. Naime, u 2016. godini povećao se broj onih koji su svoje putovanje i boravak organizirali uz pomoć agencija $(24,7 \%)$, dok se u 2014. godini njih tek 12,0 \% koristilo agencijskim uslugama. Nadalje, kako je i bilo za očekivati u obje godine, najveći dio ispitanika u destinaciju je došao automobilom (61,0\%), potom autobusom (25,0 \%) i avionom (7,9\%) (Tablica 3).

T-testom za nezavisne uzorke utvrđena je statistički značajna razlika između ispitanika iz 2014. godine i ispitanika iz 2016. godine kada je u pitanju pratnja na putovanju. Godine 2014. najviše je bilo onih koji su u destinaciju došli samo s partnerom (34,6 \%) i s prijateljima (22,0 \%). S druge strane, u 2016. godini, usporedi li se s rezultatima dobivenima dvije godine prije, značajno je više bilo onih ispitanika koji su u destinaciju došli sami (18,3\%), a manje onih koji su došli u pratnji prijatelja (16,6\%) (Tablica 3).

U kontekstu smještajnih objekata, u obje promatrane godine najviše je onih ispitanika koji su boravili u hotelima (52,0 \%), a značajan je i udio ispitanika koji su boravili u privatnom smještaju (24 \%). Između ispitanika iz 2014. i onih iz 2016. godine utvrđena je statistički značajna razlika kada je u pitanju usluga uz smještaj. U skladu s podatcima iz Tablice 3 , vidljivo je da su rezultati pokazali da je u obje promatrane godine najviše bilo onih ispitanika koji su se koristili samo uslugom smještaja (2014. - 43,0 \%; 2016. - 36,3\%), ali je u 2016. godini značajno veći udio onih koji su se odlučili za polupansion (38,8 \%), dok je udio takvih ispitanika u 2014. godini iznosio 20,1\%.

Uz navedeno, potvrđena je statistički značajna razlika između promatrane dvije skupine ispitanika kada je u pitanju prvi ili ponovljeni dolazak, namjera ponovnog dolaska kao i namjera preporuke ovih destinacija drugima. U obje promatrane godine više je onih koji destinaciju posjećuju prvi put (2014. g. takvih je bilo $50,1 \%$, a 2016. godine 57,6 \%). U oba slučaja više je onih koji imaju namjeru vratiti se kao i onih koji namjeravaju preporučiti ove destinacije drugima. Znakovit je podatak da se u 2016. godini značajno smanjio udio onih koji nemaju namjeru preporučiti destinaciju - naime u 2014. godini takvih je bilo 7,3\%, dok ih je u 2016. godini bilo tek 2,1\%. Jedan od razloga takvu rezultatu može biti i u tome što je razina zadovoljstva ispitanika statistički značajno veća među ispitanicima iz 
Tablica 3.

\section{OBILJEŽJA PUTOVANJA I BORAVKA ISPITANIKA}

\begin{tabular}{|c|c|c|c|c|}
\hline Obilježje & $\begin{array}{c}\text { Ukupno } \\
\mathrm{N}=\mathbf{1 1 9 8} \\
\%\end{array}$ & $\begin{array}{c}2014 . \\
\mathbf{N}=523 \\
\%\end{array}$ & $\begin{array}{c}2016 . \\
N=675 \\
\%\end{array}$ & $\begin{array}{c}\text { dvosmjerni } \\
\text { t-test } \\
\%\end{array}$ \\
\hline \multicolumn{5}{|l|}{ Organizacija putovanja } \\
\hline Individualno & 80,8 & 88,0 & 75,3 & \multirow{2}{*}{$\begin{array}{c}t=-5,799^{*} \\
p=0,000\end{array}$} \\
\hline Organizirano & 19,2 & 12,0 & 24,7 & \\
\hline \multicolumn{5}{|r|}{ 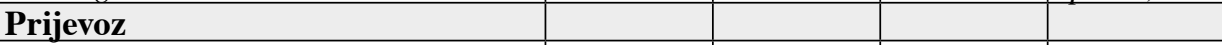 } \\
\hline Automobil & 61,0 & 64,6 & 58,3 & \multirow{6}{*}{$\begin{array}{c}t=1,876 \\
p=0,61\end{array}$} \\
\hline Autobus & 25,0 & 18,5 & 30,1 & \\
\hline Vlak & 4,1 & 4,0 & $\frac{30,1}{4,1}$ & \\
\hline Brod & 0,3 & 0,1 & 0,4 & \\
\hline Avion & 7,9 & 9,9 & 6,4 & \\
\hline Motocikl & 1,7 & 2,9 & 0,7 & \\
\hline \multicolumn{5}{|l|}{ Pratnja na putovanju } \\
\hline sami & 15,2 & 11,3 & 18,3 & \multirow{6}{*}{$\begin{array}{c}t=2,582 * * \\
p=0,010\end{array}$} \\
\hline samo s partnerom & 34,6 & 37,3 & 32,4 & \\
\hline sa članovima obitelji s djecom & 21,0 & 19,8 & 21,9 & \\
\hline s članovima obitelji bez djece & 7,8 & 6,3 & 8,9 & \\
\hline s prijateljima & 18,9 & 22,0 & 16,6 & \\
\hline sa suradnicima & 2,5 & 3,3 & 1,9 & \\
\hline \multicolumn{5}{|l|}{ Smještaj } \\
\hline Hotel s $3 *$ ili manje & 23,0 & 33,1 & 15,3 & \multirow{6}{*}{$\begin{array}{l}t=-0,140 \\
p=0,888\end{array}$} \\
\hline Hotel s $4 *$ ili $5^{*}$ & 29,0 & 15,7 & 39,3 & \\
\hline Turističko naselje & 0,7 & 0,0 & 1,1 & \\
\hline Kamp & 5,6 & 7,5 & 4,1 & \\
\hline Privatni smještaj & 24,0 & 24,4 & 23,7 & \\
\hline Rodbina/prijatelji & 11,2 & 14,5 & 8,6 & \\
\hline Hostel & 6,5 & 4,8 & 7,9 & \\
\hline \multicolumn{5}{|l|}{ Usluga uz smještaj } \\
\hline Puni pansion & 10,2 & 9,9 & 10,4 & \multirow{4}{*}{$\begin{array}{l}t=3,728^{*} \\
p=0,000\end{array}$} \\
\hline Polupansion & 28,4 & 20,1 & 34,8 & \\
\hline Noćenje i doručak & 22,2 & 27,0 & 18,5 & \\
\hline Samo smještaj & 39,2 & 43,0 & 36,3 & \\
\hline \multicolumn{5}{|l|}{ Prvi / ponovljeni dolazak } \\
\hline Prvi posjet & 54,3 & 50,1 & 57,6 & \multirow{2}{*}{$\begin{array}{c}t=2,598^{* *} \\
p=0,010\end{array}$} \\
\hline Ponovljeni posjet & 45,7 & 49,9 & 42,4 & \\
\hline \multicolumn{5}{|l|}{ Namjera ponovnog posjeta } \\
\hline$D a$ & 90,4 & 85,3 & 94,4 & \multirow{2}{*}{$\begin{array}{c}t=-5,088^{*} \\
p=0,000\end{array}$} \\
\hline $\mathrm{Ne}$ & 9,6 & 14,7 & 5,6 & \\
\hline \multicolumn{5}{|l|}{\begin{tabular}{|l} 
Namjera preporuke drugima \\
\end{tabular}} \\
\hline$D a$ & 95,7 & 92,7 & 97,9 & \multirow{2}{*}{$\begin{array}{c}t=-4,115^{*} \\
p=0,000\end{array}$} \\
\hline $\mathrm{Ne}$ & 4,3 & 7,3 & 2,1 & \\
\hline
\end{tabular}

* signifikantno uz teorijsku razinu signifikantnosti od $1 \%$

** signifikantno uz teorijsku razinu signifikantnosti od $5 \%$. 
2016. godine $u$ odnosu na ispitanike iz 2014. godine $(t=-2,974, p=0,003)$. Naime, prosječna ocjena ukupnog zadovoljstva destinacijom i njezinom ponudom u 2014. godini iznosila je 4,08, dok je dvije godine poslije iznosila 4,20 (na ljestvici od 1 u potpunosti nezadovoljan do 5 - u potpunosti zadovoljan).

\subsection{Analiza turističke potrošnje}

Rezultati ovog istraživanja nude i detaljne informacije o visini potrošnje u destinaciji u sedam glavnih kategorija: potrošnja na smještaj (koja uključuju i potrošnju na hranu i piće u smještajnom objektu), potrošnja na hranu i piće koje se konzumiraju izvan smještajnog objekta, potrošnja na zabavu i kulturu, potrošnja na sport i rekreaciju, potrošnja na kupnju (uključujući suvenire, darove, odjeću i slično), potrošnja na izlete i potrošnja na druge proizvode i usluge (uključujući medicinske tretmane, edukacijske tečajeve i slično). U ovom istraživanju isključeni su troškovi putovanja do i od destinacije. Uz navedeno, treba napomenuti da u uzorku postoje ispitanici koji nisu imali izdatke za jednu ili više kategorija potrošnje jer nisu trošili novac na određene proizvode i usluge u destinaciji. No ne postoje ispitanici koji nisu prijavili visinu izdataka za barem jednu kategoriju jer, kao što ističe Thrane (2016), ,problem nula potrošnje” (engl. zero expenditure problem) za istraživanja u kojima je zavisna varijabla ukupna turistička potrošnja ne postoji jer je gotovo nemoguće da turist uopće ne troši novac u destinaciji. S druge strane, ako zavisnu varijablu čine izdatci za određenu turističku uslugu (npr. smještaj, zabavu, sport itd.), za očekivati je da jedan dio uzorka neće trošiti na svaku kategoriju (Thrane, 2016). Stoga, prema Stynesu i Whiteu (2006), budući ispitanici unose samo visinu izdataka u kategorije u kojima su troškovi i nastali, prazni odgovori u ovom istraživanju zamijenjeni su nulom. Isti autori naglašavaju da bi se prosjek svake kategorije potrošnje, ako se te kategorije ne zamijene nulama, temeljio na različitom broju ispitanika tako da ne bi bio realan (Stynes \& White, 2006). 
Tablica 4.

PROSJEČNA DNEVNA TURISTIČKA POTROŠNJA ISPITANIKA (€)

\begin{tabular}{|l|c|c|c|c|c|c|c|}
\hline $\begin{array}{l}\text { Kategorija } \\
\text { potrošnje }\end{array}$ & \multicolumn{2}{|c|}{$\begin{array}{c}\text { Ukupno } \\
\mathbf{N = 1 1 9 8}\end{array}$} & \multicolumn{2}{c|}{$\begin{array}{c}\mathbf{2 0 1 4 .} \\
\mathbf{N = 5 2 3}\end{array}$} & \multicolumn{2}{c|}{$\begin{array}{c}\text { 2016. } \\
\mathbf{N = 6 7 5}\end{array}$} & $\begin{array}{c}\text { dvosmjerni } \\
\text { t-test }\end{array}$ \\
\hline Smještaj & 40,2 & 49,1 & 29,9 & 38,4 & 48,1 & 56,7 & $\begin{array}{c}t=-9,963^{*} \\
p=0,000\end{array}$ \\
\hline Hrana i piće & 16,7 & 20,4 & 16,6 & 21,3 & 16,8 & 19,8 & $\begin{array}{c}t=-0,275 \\
p=0,784\end{array}$ \\
\hline Zabava i kultura & 6,2 & 7,6 & 7,4 & 9,5 & 5,2 & 6,1 & $\begin{array}{c}t=4,660^{*} \\
p=0,000\end{array}$ \\
\hline Sport & 1,7 & 2,1 & 2,2 & 2,8 & 1,3 & 1,5 & $\begin{array}{c}t=3,489^{*} \\
p=0,001\end{array}$ \\
\hline Kupnja & 9,6 & 11,7 & 10,4 & 13,4 & 8,9 & 10,5 & $\begin{array}{c}t=2,367^{* *} \\
p=0,018\end{array}$ \\
\hline Izleti & 4,1 & 5,0 & 6,3 & 8,1 & 2,4 & 2,8 & $\begin{array}{c}t=9,201^{*} \\
p=0,000\end{array}$ \\
\hline Ostalo & 3,4 & 4,2 & 5 & 6,4 & 2,2 & 2,6 & $\begin{array}{c}t=8,763^{*} \\
p=0,000\end{array}$ \\
\hline Ukupno & 81,9 & 100,0 & 77,8 & 100,0 & 84,9 & 100,0 & $\begin{array}{c}t=-2,966^{*} \\
p=0,003\end{array}$ \\
\hline
\end{tabular}

* signifikantno uz teorijsku razinu signifikantnosti od $1 \%$

** signifikantno uz teorijsku razinu signifikantnosti od $5 \%$.

Kao što je prikazano u Tablici 4, prosječna dnevna potrošnja ispitanika je u 2014. godini iznosila 77,8 €, dok je 2016. godine ona bila statistički značajno viša $(84,9 €)$. U obje godine najveći dio svojeg turističkog budžeta ispitanici su trošili na smještaj, potom na hranu i piće te kupnju, što je u skladu s rezultatima istraživanja TOMAS Ljeto iz 2014. i 2017. godine (Institut za turizam, 2015, 2018). Uspoređujući rezultate iz 2014. i 2016. godine, znakovito je da se visina prosječne dnevne potrošnje ispitanika statistički značajno promijenila u šest od ukupno sedam kategorija potrošnje. Tako je T-testom utvrđena statistički značajna promjena u visini dnevne potrošnje na smještaj, zabavu i kulturu, sport, kupnju, izlete i druge proizvode i usluge u destinaciji. S druge strane, potvrđeno je da uz teorijsku razinu signifikantnosti od $5 \%$ nema statistički značajne razlike između dviju promatranih grupa ispitanika kada je riječ o dnevnoj potrošnji na hranu i piće. Ispitanici su 2014. godine u prosjeku na hranu i piće trošili 16,6 €, a 2016. godine $16,8 €$. 
Uz promjene u visini dnevne potrošnje u 2016. godini u odnosu na 2014. godinu, očigledna je i promjena u njezinoj strukturi. Naime, u 2014. godini ispitanici su na smještaj u prosjeku trošili dnevno $29,9 €$, što je činilo 38,4 \% njihove ukupne dnevne potrošnje, a 2016. godine na smještaj se u prosjeku dnevno trošilo $48,1 €$, odnosno čak 65,7 \% dnevne potrošnje ispitanika. Važan je i podatak da je u 2016. godini smanjena dnevna potrošnja na zabavu i kulturu (5,2€, odnosno 6,1 \% ukupne dnevne potrošnje) u odnosu na 2014. godinu kada se na potrošnju na zabavu i kulturu trošilo 9,5 \% dnevnog budžeta. Slična je situacija i s potrošnjom na izlete koja je drastično opala u 2016. godini kada je činila samo 2,8 \% prosječne dnevne potrošnje turista. Analiza strukture turističke potrošnje ispitanika ukazuje na činjenicu da je do povećanja ukupne prosječne potrošnje u 2016. godini u odnosu na 2014. godinu u najvećoj mjeri došlo upravo zbog značajno više potrošnje na smještaj, dok se potrošnja u svim ostalim kategorijama (osim hrane i pića) značajno smanjila. Ovakvi rezultati ukazuju na potrebu diverzificiranja i inoviranja turističke ponude ovih destinacija, posebice kada je riječ o proizvodima i uslugama izvan smještajnih kapaciteta.

U sljedećem koraku analize podataka provedene su dvije regresijske analize s ciljem utvrđivanja čimbenika koji su utjecali na visinu turističke potrošnje u destinaciji, zasebno na ispitanicima koji su u destinaciji boravili 2014. godine i onima koji su tamo boravili 2016. godine. Mnogi autori slijede ekonometrijsku praksu i u svojim analizama primjenjuju prirodni logaritam potrošnje (primjerice Disegna \& Osti, 2016; Downward \& Lumsdon, 2003; García-Sánchez et al., 2013; Marrocu et al., 2015; Thrane, 2014; 2016). Stoga se, u skladu s prethodnim istraživanjima, i u ovom istraživanju primjenjivao prirodni logaritam ukupne dnevne potrošnje po osobi kao zavisna varijabla u modelima OLS regresije (Tablice 5 i 6).

Wang \& Davidson (2010) ističu da nezavisne varijable primijenjene u postojećim studijama još uvijek nedovoljno objašnjavanju razinu turističke potrošnje jer ih većina bilježi prilično nizak $\mathrm{R}^{2}$ koji je ponekad ispod 0,2 , što znači da uključene nezavisne varijable objašnjavaju najviše $20 \%$ varijance potrošnje. Navedeno implicira potrebu uključivanja, uz uobičajene, dodatnih varijabli koje dosad nisu u dovoljnoj mjeri bile obuhvaćene istraživanjima povezanima s turističkom potrošnjom. U ovom istraživanju uključena je jedna psihografska varijabla (ukupno zadovoljstvo turista destinacijom) koja je rijetko testirana u ovakvim modelima unatoč činjenici da su brojne studije potvrdile da zadovoljstvo turista utječe na njihovu lojalnost (Bernini \& Cagnone, 2012; Marcussen, 2011) kao i na preporuku destinacije drugima (Mendes et al., 2010). 


\section{Tablica 5.}

\section{REGRESIJSKI MODEL 1: ČIMBENICI KOJI UTJEČU NA DNEVNU TURISTIČKU POTROŠNJU (2014.)}

\begin{tabular}{|c|c|c|c|c|c|}
\hline \multirow{2}{*}{ Varijable } & \multicolumn{2}{|c|}{$\begin{array}{c}\text { Nestandardizirani } \\
\text { koeficijenti }\end{array}$} & \multirow{2}{*}{ Sig. } & \multicolumn{2}{|c|}{$\begin{array}{c}\text { Pokazatelji } \\
\text { kolinearnosti }\end{array}$} \\
\hline & B & $\begin{array}{c}\text { Std. } \\
\text { Error }\end{array}$ & & Tolerancija & VIF \\
\hline (Konstanta) & 3,788 & 0,146 & 0,000 & & \\
\hline $\begin{array}{l}\text { Subregija (0 - Opatijska rivijera; } \\
\text { 1-Rijeka i prsten) }\end{array}$ & $0,093 * *$ & 0,042 & 0,028 & 0,951 & 1,051 \\
\hline Spol $(0-m u s ̌ k i ; ~ 1-z ̌ e n s k i)$ & $-0,052$ & 0,040 & 0,194 & 0,986 & 1,015 \\
\hline Primanja kućanstva & $0,104 *$ & 0,012 & 0,000 & 0,846 & 1,182 \\
\hline Smještaj $(0$ - hotel, 1 -ostalo $)$ & $-0,389 *$ & 0,041 & 0,000 & 0,951 & 1,051 \\
\hline Duljina boravka & $-0,008 *$ & 0,002 & 0,000 & 0,965 & 1,036 \\
\hline Broj posjeta & $-0,006$ & 0,004 & 0,159 & 0,922 & 1,084 \\
\hline $\begin{array}{l}\text { Prijevozno sredstvo } \\
(0-\text { automobil, } 1-- \text { ostalo })\end{array}$ & 0,083 & 0,043 & 0,053 & 0,936 & 1,068 \\
\hline $\begin{array}{l}\text { Zemlja porijekla }(0-\text { domaći; } \\
1 \text {-strani) }\end{array}$ & $-0,020$ & 0,061 & 0,740 & 0,862 & 1,160 \\
\hline Ukupno zadovoljstvo destinacijom & 0,046 & 0,032 & 0,148 & 0,963 & 1,038 \\
\hline
\end{tabular}

Napomena: $\mathrm{R}^{2}=0,341 ; \mathrm{F}(9,513)=29,522 ; \mathrm{p}<0,000$; Zavisna varijabla: log prosječne dnevne potrošnje; VIF - variance inflation factor;

* signifikantno uz teorijsku razinu signifikantnosti od $1 \%$

** signifikantno uz teorijsku razinu signifikantnosti od $5 \%$.

Prema rezultatima prikazanima u Tablici 5, model koji uključuje ispitanike koji su boravili na području Opatijske rivijere i Rijeke i riječkog prstena, u 2014. godini objašnjava $34,1 \%$ njihove turističke dnevne potrošnje u destinaciji $\left(\mathrm{R}^{2}=\right.$ $0,341 ; \mathrm{F}(9,513)=29,522 ; \mathrm{p}<0,00)$.

Od ukupno devet nezavisnih varijabli, u prvom regresijskom modelu potvrđeno je kako njih četiri statistički značajno utječe na dnevnu potrošnju ispitanika. Naime, potvrđeno je da turisti koji su boravili na području Rijeke i riječkog prstena (u indikatoru varijabli označeni kodom 1) dnevno troše više od onih koji borave na Opatijskoj rivijeri (referentna grupa). Kako je i bilo za očekivati, potvrđeno je da su primanja kućanstva također statistički značajan prediktor turističke potrošnje - oni koji imaju viša primanja u destinaciji troše više u odnosu na one s nižim primanjima. Ovakav su rezultat potvrdili brojni drugi autori, primjerice 
Brida \& Scuderi (2013), Fredman (2008), García-Sánchez et al. (2013), Marrocu et al. (2015), Thrane (2016). Nadalje, rezultati ukazuju na to da oni koji odsjedaju u hotelima imaju tendenciju trošiti više u destinaciji u odnosu na one koji odsjedaju u drugim tipovima smještajnih kapaciteta. Ovakav rezultat u skladu je s rezultatima do kojih su došli Agarwal i Yochum (1999), García-Sánchez et al. (2013), Laesser \& Crouch (2006), Mayer \& Vogt (2015), Svensson et al. (2011). Uz navedeno, u ovom je modelu potvrđeno da je i duljina boravka važan prediktor dnevne turističke potrošnje - naime, što je boravak dulji, to je i prosječna dnevna potrošnja niža. Do istog su rezultata, među ostalima, došli i Alegre et al. (2011), Cannon \& Ford (2002), Downward \& Lumsdon, (2003), Disegna \& Osti (2016), Nicolau i Mas, 2005. U prvom regresijskom modelu, uz teorijsku razinu signifikantnosti od $5 \%$, spol, broj posjeta, prijevozno sredstvo, zemlja porijekla kao ni ukupno zadovoljstvo ispitanika nisu potvrđeni kao značajni prediktori prosječne dnevne potrošnje ispitanika koji su boravili u promatranim destinacijama 2014. godine.

\section{Tablica 6.}

\section{REGRESIJSKI MODEL 2: ČIMBENICI KOJI UTJEČU NA DNEVNU TURISTIČKU POTROŠNJU (2016.)}

\begin{tabular}{|c|c|c|c|c|c|}
\hline \multirow{2}{*}{ Varijable } & \multicolumn{2}{|c|}{$\begin{array}{c}\text { Nestandardizirani } \\
\text { koeficijenti }\end{array}$} & \multirow{2}{*}{ Sig. } & \multicolumn{2}{|c|}{$\begin{array}{c}\text { Pokazatelji } \\
\text { kolinearnosti }\end{array}$} \\
\hline & B & $\begin{array}{l}\text { Std. } \\
\text { Error }\end{array}$ & & Tolerancija & VIF \\
\hline (Konstanta) & 4,098 & ,119 & ,000 & & \\
\hline $\begin{array}{l}\text { Subregija (0-- Opatijska rivijera; } \\
\text { l-Rijeka i prsten) }\end{array}$ & 0,017 & 0,041 & 0,674 & 0,934 & 1,070 \\
\hline Spol (0-muški; 1 -ženski) & $-0,073$ & 0,037 & 0,051 & 0,977 & 1,023 \\
\hline Primanja kućanstva & $0,049 *$ & 0,010 & 0,000 & 0,886 & 1,129 \\
\hline Smještaj $(0-$ hotel, 1 -ostalo $)$ & $-0,500 *$ & 0,038 & 0,000 & 0,950 & 1,052 \\
\hline Duljina boravka & $-0,010^{*}$ & 0,003 & 0,002 & 0,927 & 1,079 \\
\hline Broj posjeta & $-0,015^{*}$ & 0,003 & 0,000 & 0,924 & 1,082 \\
\hline $\begin{array}{l}\text { Prijevozno sredstvo (0 - automobil, } \\
1 \text {-- ostalo) }\end{array}$ & $-0,028$ & 0,038 & 0,457 & 0,979 & 1,021 \\
\hline Zemlja porijekla $(0$ - domaći; 1 - strani) & $0,173^{*}$ & 0,051 & 0,001 & 0,895 & 1,117 \\
\hline Ukupno zadovoljstvo destinacijom & $0,051 * *$ & 0,025 & 0,044 & 0,954 & 1,048 \\
\hline
\end{tabular}

Napomena: $\mathrm{R}^{2}=0,316 ; \mathrm{F}(9,664)=34,117 ; \mathrm{p}<0,000$; Zavisna varijabla: log prosječne dnevne potrošnje; VIF - variance inflation factor;

* signifikantno uz teorijsku razinu signifikantnosti od $1 \%$

** signifikantno uz teorijsku razinu signifikantnosti od $5 \%$. 
Drugi regresijski model objašnjava 31,6 \% ukupne varijance prosječne dnevne turističke potrošnje turista koji su u ovim destinacijama boravili 2016. godine $\left(\mathrm{R}^{2}=0,316 ; \mathrm{F}(9,664)=34,117 ; \mathrm{p}<0,000\right)$. Slijedom podataka prezentiranih $\mathrm{u}$ Tablici 6 , u ovom slučaju od ukupno devet nezavisnih varijabli njih šest statistički značajno objašnjava prosječnu dnevnu potrošnju ispitanika. Uz varijable koje su se pokazale statistički značajnima i u prvom modelu (primanja kućanstva, tip smještajnog objekta i duljina boravka), u ovom je modelu kao značajan prediktor potrošnje potvrđen broj posjeta, odnosno lojalnost turista destinaciji. Rezultati ukazuju na to da oni koji su više puta posjetili destinaciju imaju tendenciju trošiti manje za razliku od onih koji u destinaciji borave prvi put. Autori kao što su Alegre i Cladera (2010), Jang et al. (2004), Sato et al. (2014) također su potvrdili negativnu statistički značajnu vezu između onih koji su više puta boravili u destinaciji i onih koji u njoj borave prvi put. Nadalje, u drugom modelu potvrđena je veza između zemlje porijekla i prosječne dnevne turističke potrošnje. U skladu s rezultatima, stani turisti troše više u destinaciji u odnosu na domaće turiste (Tablica 6). Kastenholz (2005), Thrane i Farstad (2012) također su potvrdili da nacionalnost utječe na visinu turističke potrošnje, dok su Marrocu et al. (2015) u svojoj studiji također potvrdili da strani gosti obično troše više nego domaći. Uz navedeno, znakovit je rezultat koji ukazuje na to da je ukupno zadovoljstvo turista destinacijom i njezinom ponudom statistički značajno povezano s visinom njihove dnevne potrošnje. U ovom slučaju važno je naglasiti da se zadovoljstvo, kao jedna od psihografskih varijabli, vrlo rijetko uključivalo u modele koji su istraživali determinante turističke potrošnje (Kim et al. 2010). Rezultati druge regresijske analize pokazali su da oni ispitanici koji su zadovoljniji u destinaciji troše više u odnosu na one koji su njome manje zadovoljni. Navedeno potvrđuje koliko je važno kontinuirano pratiti zadovoljstvo turista jer ne samo da je vjerojatnije da će zadovoljni turisti ponovno posjetiti destinaciju ili je preporučiti drugima, već će u destinaciji trošiti više. S obzirom na činjenicu da su drugi autori vrlo rijetko testirali vezu između zadovoljstva turista i razine ostvarene potrošnje, ovaj je nalaz vrlo vrijedan i u metodološkom kontekstu.

Rezultati dvaju regresijskih modela ukazuju i na to da je razina turističke potrošnje statistički značajno različita u dvjema promatranim godinama ispitivanja kao i na to kako se razlikuju i neki od čimbenika koji utječu na njezinu visinu. Naime, u obje godine potvrđena je pozitivna veza između prosječnih primanja kućanstva i visine turističke potrošnje kao i negativna veza između duljine boravka i visine potrošnje. U oba slučaja potvrđeno je da i tip smještajnog objekta utječe na visinu prosječne dnevne potrošnje ispitanika. Istovremeno je utvrđeno da je na visinu turističke potrošnje ispitanika koji su u promatranim destinacijama boravili 2014. godine utjecala i činjenica jesu li boravili na području Opatijske rivijere ili pak Rijeke i riječkog prstena. S druge strane, rezultati su ukazali da to nije slučaj kada su u pitanju ispitanici koji su u tim destinacijama boravili u ljeto 2016. 
godine. Naime, kod njih je potvrđeno da broj posjeta, zemlja porijekla kao i stupanj zadovoljstva destinacijom statistički značajno utječu na razinu njihove dnevne potrošnje. Posebno je važno istaknuti da su rezultati drugog modela potvrdili da turisti koji su zadovoljniji destinacijom i njezinom ponudom imaju tendenciju trošiti više, što potvrđuje važnost kontinuiranog istraživanja stavova turista. Naime, na taj način destinacijski menadžment dobiva kvalitetnu informacijsku bazu na temelju koje se mogu pratiti stavovi turista koji ukazuju na ono što je potrebno mijenjati i unapređivati u destinaciji. Djelujući u skladu s dobivenim rezultatima takvih istraživanja, destinacijski menadžment može ciljano i učinkovito mijenjati elemente turističke ponude, usklađujući je s potrebama i očekivanjima turista, te posljedično utjecati i na povećanje turističke potrošnje.

\section{Zaključna razmatranja}

Istraživanja turističke potrošnje na razini destinacije vrlo su važna jer je utvrđivanje njezinih odrednica korisno u smislu razumijevanja obrazaca ponašanja turista-potrošača kao i utvrđivanja visokoprofitnih tržišnih segmenata, što će u konačnici pomoći povećanju ekonomskih učinaka turizma. U ovom su se radu uspoređivale razina, struktura i determinante turističke potrošnje ostvarene u 2014. i 2016. godini. S obzirom na to da su rezultati istraživanja potvrdili, među ostalim, da postoje razlike i u razini i u determinantama turističke potrošnje u 2016. godini u odnosu na 2014. godinu potvrdila se potreba kontinuiranog istraživanja stavova i potrošnje turista u cilju postizanja dugoročno održive turističke destinacije. Jednom kada menadžment destinacije ima informaciju o obilježjima i stavovima turista i posebice podatke o visini, strukturi i čimbenicima njihove turističke potrošnje, stvara se kvalitetna podloga za odlučivanje o budućim pravcima razvoja destinacije. Uslijed ograničene raspoloživosti resursa, poznavanje specifičnosti turista koji borave u destinaciji, njihovih stavova o destinaciji kao i njihove potrošnje omogućuje ciljanu alokaciju sredstava onim elementima turističke ponude koji će ih potaknuti na izdašniju turističku potrošnju. U tom je kontekstu važno istaknuti da su rezultati istraživanja potvrdili da turisti koji su zadovoljniji destinacijom i njezinom ponudom imaju tendenciju trošiti više. Navedeno ne ukazuje na potrebu kvantitativnog povećanja kapaciteta, već prvenstveno na potrebu unaprjeđenja kvalitete svih elemenata turističkog proizvoda ovih destinacija. Obje destinacije iz godine u godinu unaprjeđuju i obogaćuju svoju ponudu, no očigledan je nedostatak inovativnih i kreativnih rješenja koja će turiste potaknuti na aktivno sudjelovanje i interakciju, što će posljedično rezultirati kvalitetnim turističkim doživljajem.

Naposljetku je važno istaknuti i ograničenja ovog istraživanja koja se ogledaju u činjenici da je istraživanje provedeno samo na području Opatijske rivije- 
re i Rijeke i riječkog prstena tijekom ljetnih mjeseci, stoga rezultate nije uputno generalizirati na ostale destinacije. Analiza prethodnih istraživanja pokazala je odstupanja u rezultatima povezanima s odrednicama turističke potrošnje jer značajnost i smjer utjecaja pojedinih varijabli na turističku potrošnju varira od istraživanja do istraživanja. Navedeno ukazuje na to da postoji potreba kontinuiranog istraživanja turističke potrošnje, njezine visine, strukture i njezinih determinanti u okviru pojedine destinacije upravo zbog toga što je svaka destinacija jedinstvena i specifična sama po sebi. Stoga se preporučuje provoditi slična istraživanja i u drugim destinacijama kako bi se rezultati mogli uspoređivati i, u konačnici, generalizirati. S obzirom na problem sezonalnosti, posebnu vrijednost dali bi rezultati istraživanja o turističkoj potrošnji provedenih izvan sezone. To bi omogućilo i vremensko uspoređivanje rezultata. Za očekivati je kako bi informacije o stavovima, razini i strukturi turističke potrošnje izvan sezone ukazivale na drugačije obrasce potrošnje i ponašanja turista, što bi također bilo važno pri odlučivanju i planiranju daljnjeg razvoja destinacije.

Uz navedeno, bilo bi važno da modeli budućih istraživanja uključuju još više psihografskih varijabli, a ne samo ukupno zadovoljstvo destinacijom, upravo zato što je oskudan broj autora ispitao njihovu vezu s ostvarenom turističkom potrošnjom.

\section{Literatura:}

Agarwal, V. B. \& Yochum, G. R. (1999). Tourist spending and race of visitors. Journal of Travel Research, 38(2), 173-176.

Alegre, J. \& Cladera, M. (2010). Tourist expenditure and quality: Why repeat visitors can spend less than first-timers. Tourism Economics, 16(3), 517-533.

Alegre, J., Cladera, M. \& Sard, M. (2011). Analysing the influence of tourist motivations on tourist expenditure at a sun-and-sand destination. Tourism Economics, 17(4), 813-832.

Bernini, C. \& Cagnone, S. (2012). Analysing tourist satisfaction at a mature and multiproduct destination. Current Issues in Tourism, doi: http://dx.doi.org/10.1080/13683 500.2012 .702737

Brida, J. G. \& Scuderi, R. (2013). Determinants of tourist expenditure: A review of microeconometric models. Tourism Management Perspectives, 6, 28-40.

Cannon, T. F. \& Ford, J. (2002). Relationship of demographic and trip characteristics to visitor spending: An analysis of sports travel visitors across time. Tourism Economics, 8(3), 263-271.

Chen, C.-M. \& Chang, K.-L. (2012). The influence of travel agents on travel expenditures. Annals of Tourism Research, 39(2), 1258-1263. 
Corte, V. D., Sciarelli, M., Cascella, C. \& Gaudio, G. D. (2015). Customer Satisfaction in Tourist Destination: The Case of Tourism Offer in the City of Naples. Journal of Investment and Management, 4(1), 39-50.

Craggs, R. \& Schofield, P. (2009). Expenditure-based segmentation and visitor profiling at the quays in Salford, UK. Tourism Economics, 15(1), 243-260.

Disegna, M. \& Osti, L. (2016). Tourists' expenditure behaviour: the influence of satisfaction and the dependence of spending categories. Tourism Economics, 22(1), 5-30.

Downward, P. \& Lumsdon, L. (2003). Beyond the demand for day-visits: An analysis of visitor spending. Tourism Economics, 9(1), 67-76.

Državni zavod za statistiku. (2015). Dolasci i noćenja turista u 2014. Zagreb: Državni zavod za statistiku.

Državni zavod za statistiku. (2017). Dolasci i noćenja turista u 2016. Zagreb: Državni zavod za statistiku.

Frechtling, D. C. (2006). An assessment of visitor expenditure methods and models. Journal of Travel Research, 45(1), 26-35.

Fredman, P. (2008). Determinants of visitor expenditures in mountain tourism. Tourism Economics, 14(2), 297-311.

García-Sánchez, A., Fernández-Rubio, E. \& Collado, M. D. (2013). Daily expenses of foreign tourists, length of stay and activities: Evidence from Spain. Tourism Economics, 19(3), 613-630.

Hung, W.-T., Shang, J.-K. \& Wang, F.-C. (2012). Another look at the determinants of tourism expenditure. Annals of Tourism Research, 39(1), 495-498.

Institut za turizam. (2015). Stavovi i potrošnja turista u Hrvatskoj - TOMAS ljeto 2014. Zagreb: Institut za turizam.

Institut za turizam. (2018). Stavovi i potrošnja turista u Hrvatskoj - TOMAS ljeto 2017. Zagreb: Institut za turizam.

Jang, S. C., Bai, B., Hong, G.-S. \& O’Leary, J. T. (2004). Understanding travel expenditure patterns: A study of Japanese pleasure travelers to the United States by income level. Tourism Management, 25(3), 331-341.

Kastenholz, E. (2005). Analysing determinants of visitor spending for the rural tourist market in North Portugal. Tourism economics, 11(4), 555-569.

Kim, S.S., Prindeaux, B. \& Chon, K. (2010). A comparison of results of three statistical methods to understand the determinants of festival participants' expenditures. International Journal of Hospitality Management, 29, 297-307.

Laesser, C. \& Crouch, G. I. (2006). Segmenting markets by travel expenditure patterns: The case of international visitors to Australia. Journal of Travel Research, 44(4), 397-406.

Legohérel, P. \& Wong, K. K. F. (2006). Market segmentation in the tourism industry and consumers' spending: What about direct expenditures? Journal of Travel and Tourism Marketing, 20(2), 15-30. 
Mak, J. (2004). Tourism and the Economy. Understanding the Economics of Tourism. Honolulu: University of Hawai'i Press.

Marcussen, C. H. (2011). Determinants of spending by Danish travellers. Anatolia, 22(1), 47-55.

Marrocu, E., Paci, R. \& Zara, A. (2015). Micro-economic determinants of tourist expenditure: A quantile regression approach. Tourism Management, 50, 13-30.

Mayer, M. \& Voght, L. (2016). Economic effects of tourism and its influencing factors: An overview focusing on the spending determinants of visitors. Zeitschrift fuer Tourismuswissenschaft, 8(2), 169-198.

Mendes, J., Oom do Valle, P., Guerreiro, M. \& Silva, J.A. (2010). The tourist experience: Exploring the relationship between tourist satisfaction and destination loyalty. Tourism - An International Interdisciplinary Journal, 58(2), 111-127.

Mihalič, T. (2002). Tourism and Economic Development Issues. In R. Sharpley i D. J. Telfer (Eds.), Tourism and Development: Concepts and Issues (81-111). Clevedon, UK: Channel View Publications.

Nicolau, J. \& Mas, F. (2005). Heckit modeling of tourist expenditure: Evidence from Spain. International Journal of Service Industry Management, 16(3), 271-293.

Sato, M., Jordan, J. S., Kaplanidou, K. \& Funk, D. C. (2014). Determinants of tourists' expenditure at mass participant sport events: A five year analysis. Current Issues in Tourism, 17(9), 763-771.

Stynes, D.J. \& White, E.M. (2006). Reflections on measuring recreation and travel spending. Journal of Travel Research, 45(1), 8-16.

Svensson, B., Moreno, P. \& Martín, D. (2011). Understanding travel expenditure by means of market segmentation. Service Industries Journal, 31(10), 1683-1698.

Thrane, C. (2014). Modelling micro-level tourism expenditure: Recommendations on the choice of independent variables, functional form and estimation technique. Tourism Economics, 20(1), 51-60.

Thrane, C. (2016). The determinants of Norwegians' summer tourism expenditure: foreign and domestic trips. Tourism Economics, 22(1), 31-46.

Thrane, C. \& Farstad, E. (2012). Nationality as a segmentation criterion in tourism research: the case of international tourists' expenditures while on trips in Norway. Tourism Economics, 18(1), 203-217.

Wang, Y. \& Davidson, M. C. G. (2010). A review of micro analyses of tourist expenditure. Current Issues in Tourism, 13(6), 507-524.

Wang, Y., Rompf, P., Severt, D. \& Peerapatdit, N. (2006). Examining and identifying the determinants of travel expenditure patterns. International Journal of Tourism Research, 8(5), 333-346.

Zhang, L., Qu, H., \& Ma, J. E. (2010). Examining the relationship of exhibition attendees' satisfaction and expenditure: The case of two major exhibitions in China. Journal of Convention \& Event Tourism, 11(2), 100-118. 


\title{
CHANGES IN THE TOURIST EXPENDITURE PATTERNS IN OPATIJA AND RIJEKA
}

\author{
Summary
}

The purpose of this paper is to determine whether changes in the level, structure and determinants of tourist expenditure that is recorded in 2016 in relation to that recorded in 2014 exist. The results are based on a survey conducted during summer months of 2014 and 2016 in Opatija and Rijeka (Croatia). The quantitative analysis is based on a sample of 1198 respondents. The respondents were divided into two groups, those who visited these destinations in 2014 and those who stayed there in 2016. Independent t-tests were conducted to determine significant differences between two groups of respondents. Finally, two regression analyses were made to identify their expenditure determinants. The results reported that there are significant differences in the level and the structure of tourism expenditure between two groups. In addition, the main findings indicate that different predictors influence the daily expenditure levels reported in 2014 and 2016.

Key words: tourist expenditure, expenditure determinants, expenditure structure, tourism 